\title{
Effect of Corps Rotation and Sequence Weed Control Treatments on Weeds and Faba Bean Productivity
}

\author{
A.A.O Fakkar ${ }^{(1) \#}$ and Yasser A.M. Khlifa ${ }^{(2)}$ \\ (1) Weed Central Lab, Agricultural Research Center, Giza, Cairo, Egypt; (2) Agronomy \\ Department, Factory of Agriculture Al Azhar University (Assiut Branch), Assiut, Egypt.
}

\begin{abstract}
CROP rotation is thought to reduce weed density, hence preventing the domination of some weeds problem. Variance in weed population between cropping systems may be the direct result of crop rotation. Two rotation experiments in a long - term study were carried out at Shandaweel Res. St., Sohag Governorate in Upper Egypt from 2014/15, 2015/16 and 2016/17 winter seasons. The Area used for agriculture has not changed over the three seasons. Plots were not changed in every treatment in the sense that all experimental pieces received the same treatment in the three seasons of summer and winter.
\end{abstract}

Results showed that of crop rotation system (Faba bean/maize/faba bean/maize) gave the height effect in decreased on number and weight of grassy, broad-leaved and total weeds and increased weight of pods, weight of seeds/plant, 100-seed weight and seed yield ( $\mathrm{arad} / \mathrm{fad})$ compared with (Faba bean/peanut/faba bean/peanut) in seasons 2014/15,2015/16 and 2016/17, respectively. Gradually increased the weight of pods and seeds/plant, 100-seed weight and seed yield ( $\mathrm{arad} / \mathrm{fad})$ from season to season using of herbicide or hand hoeing compared with control.

Significant positive correlation values were detected between the number and weight of all weeds spices in both seasons. A correlation value was negative between the number and weight of weeds and seed yield $(\mathrm{ard} / \mathrm{fad})$ and 100-seed weight but a correlation value was positive between yield and it's components.

Economic evaluation of the results indicated that using crop rotation system (Faba bean/ maize/faba bean/maize) gave the highest economic values in the average of three seasons for all economic evaluation.

Keywords: Crop rotation, Weed control, Faba bean, Maize, Peanut Fusilade super Basagran, Hand hoeing.

\section{Introduction}

Crop rotation is one of the oldest methods and most effective cultural control strategies. It means the planned order of specific crops planted on the same field. Legumes are great importance in rotation, in general rain fed areas in which the fallow lands are intensive. Liebman \& Dyck (1993) showed that varied crop rotations tend to diminish the development of a few primary weed species by offering distinct, sowing and harvest times, different life cycles and different possibilities for weed control.

Powerful weed management demand the integration of crop sequences with other biological, physical and chemical techniques to promote crop dominance over weeds (AlAkkad, 1994). Karlen et al. (1994) stated that crop rotation that alternate different crop species generally interrupt weed growth cycles, thus improving crop yields. Hassanein et al (1994 ;1995; 1999 and 2000) showed that faba bean/ wheat/faba bean/wheat sequences decreased weeds competition and increased yield through reducing weeds infestation and decreasing seed bank in soil. Also, Using the combined herbicides under crop rotation to increase yield and decrease weeds. A rotation is "the sequence of crops grown in succession on a particular field" (Wibberley, 1996). Rotational management strategies affected the growth of the weed population (Davies et al., 1997). Reduction in weed effects through adapted crop management (prevention) involves any aspect of management that favors the crop relative to the weed, i.e., crop rotations ( $\mathrm{Wu}$ et al., 1999). Kropff \& Walter (2000) reveled that weed management has always been a key issue

"Corrresponding author email: yasserbeet@yahoo.com

DOI: 10.21608 /agro.2018.4159.1106

C2018 National Information and Documentation Center (NIDOC) 
in most agricultural production systems. Zentner et al. (2002) explained that crop rotation is one of the main practices in sustainable agricultural systems, because of its effects on soil fertility and reduction weed competition. Thorup et al. (2003) stated that less diverse crop rotations, such as arable crop rotations with high proportions of cereals for grain, may offer good opportunities for problematic weeds to propagate, since the growing conditions are very similar from one year to the next. Buhler (2004) showed that crop rotation is an effective tool for weed management by changing the pattern of distribution which diversifies selection pressure. This variegation prevents the proliferation of weed species to be well suited to the practices corresponding with a single crop (Filizadeh et al., 2007). It is noteworthy that assorted rotation systems in which legumes are involved are applied in countries with advanced agriculture. Stanger \& Lauer (2008) showed that crop rotation system containing different crops, especially faba bean (legumes) is thought to be more convenient which is widely used, due to their various advantages.

Herbicides are very important of the available methods for annual weeds. Ebaid (1990) found that hand weeding lowered the number of weeds in faba bean by 54.2-61.4plants $/ \mathrm{m}^{2}$, respectively, compared to untreated control 134.0-152.0plants/ $\mathrm{m}^{2}$ and increased crop seed yields by $9.5-9.8 \mathrm{ardab} /$ faddan, respectively, compared to untreated control 6.8-7.0ardab/faddan. Heath et al. (1991) noted that Bentazone controlled many broadleaved weeds applied post-em. at the full dose $(1.44 \mathrm{~kg} /$ ha). Nehra \& Malik (1999) showed that two hand weeding at 30 and 60 DAS gave an effective level of weed control. El-Metwally \& Ahmed (2001) indicated that the best control and highest seed yield of faba bean were achieved by application of Bentazon and Fluazifop-butyl. Saad El-Din (2003) noted that the best control of broad-leaved weeds and highest seed yield of faba bean were achieved by application of Bentazon. Ismail \& Fakkar (2008) reported that the best treatments for faba bean seed yield, dry weight of weeds and broomrape were achieved from hand hoeing and pulling twice and Bazagran + Fusilade herbicides. Abasalt et al. (2014) showed that dry weight of weed was obtained Bentazon followed by hand weeding once accompanied with increased broad bean yield.

The objective, of this studying determine more suitable crop rotation systems for faba bean by comparing different rotation systems in which numerous crops are involved, with respect to improvement crop yield and economic profitability.

\section{Materials and Methods}

Two field experiments were conducted at Shandaweel Agricultural Research Station, Sohag Governorate, Egypt during three successive winter seasons of 2014/15, 2015/16 and 2016/17 winter seasons and two summer seasons 2015 and 2016 to study effect of two crop rotation and three weed control treatments sequence on weeds yield and yield component of faba bean crop in 2014/15, 2015/16 and 2016/17 seasons. The experimental design was split-plot with three replicates.

\section{Main plots: crop rotation}

1-Faba bean/maize/faba bean/maize/faba bean ( $1^{\text {st }}$ system).

2-Faba bean/peanut/faba bean/peanut/faba bean $\left(2^{\text {nd }}\right.$ system $)$.

Sub plots: weed control treatments of sequence

1- Harness at $1.0 \mathrm{~L} / \mathrm{fad}$ at pre-emergence applied on weeds of maize in summer /Bazagran $48 \%$ AS at $500 \mathrm{cc} / \mathrm{fad}+$ Fusilade super $12.5 \%$ $\mathrm{EC}$ at $1.0 \mathrm{~L} /$ fad at 30 days after planting applied on weeds of peanut in summer and faba bean in winter.

2- Hand hoeing twice at 18 and 30 days after planting on weeds in summer and winter crops.

3- Un-weeded in summer and winter crops.

\begin{tabular}{|c|c|c|c|c|}
\hline \multicolumn{5}{|c|}{ Treatments on different crops } \\
\hline Crops & & Peanut & Maize & Faba bean \\
\hline \multirow[t]{4}{*}{ Seasons } & & $2015-2016$ & $2015-2016$ & $2014 / 15-2015 / 16-2016 / 17$ \\
\hline & 1 & Bazagran + Fusilade super & Harness & Bazagran + Fusilade super \\
\hline & 2 & Hand hoeing twice & Hand weeding twice & Hand hoeing twice. \\
\hline & 3 & Un-weeded & Un-weeded & Un-weeded \\
\hline
\end{tabular}


Area used for agriculture has not changed over the three seasons. Plots were not changed in every treatment in the sense that all experimental pieces received the same treatment in the three seasons of summer and winter.

All tested herbicides were applied by knapsack sprayer equipped with a single nozzle boom was used and spray solution volume was 200L water/ fad in all cases.

Faba bean seeds Giza-843 cultivar was sown on one side of the ridge, at $20 \mathrm{~cm}$ apart. The experimental unit area was $10.5 \mathrm{~m}^{2}$, it contains 6 ridges with $3 \mathrm{~m}$ length and $60 \mathrm{~cm}$ between ridges. The experimental soil was clay loam in texture with $\mathrm{pH}$ value of 7.8 , organic mater content of $1.6 \%$, total $\mathrm{N} 1.2 \%$, available $\mathrm{P}$ and $\mathrm{K}$ of $7.5,160 \mathrm{ppm}$, respectively. The other normal agricultural practices, i.e. irrigation, insects and disease control, were carried out according to the officinal recommendations. Planting seasons (planting date, harvest date, seeding rate and variety data are illustrated in Table A

\section{Data recorded \\ Weed control}

The dominant weed species in the present study were recorded: Avena spp. (Wild oats) and Phalaris sp. (Canary grass) as annual grassy weeds; Emex spinosus (Spiny emex), Chenopodium sp. (Lambsquarters), Brassica sp. (Kabar, black mustard), Rumex dentatus (Curly dock) and Sonchus oleraceus (Annual sowthistle) as annual broad-leaved weeds in 2014/15, 2015/16 and 2016/17 seasons.

Weeds were hand pulled from one square meter of each plot after month from last treatment, after 60 from sowing were identified and classified into the following group: (1) Numbers $\left(\mathrm{m}^{2}\right)$ and dry weight of grassy weeds $\left(\mathrm{g} / \mathrm{m}^{2}\right)$. (2) Numbers $\left(\mathrm{m}^{2}\right)$ and dry weight of broad-leaved weeds $\left(\mathrm{g} / \mathrm{m}^{2}\right)$. (3) Numbers $\left(\mathrm{m}^{2}\right)$ and dry weight of total grassy and of broadleaved weeds $\left(\mathrm{g} / \mathrm{m}^{2}\right)$. Weeds were air dried for 2 days and then dried in an oven at $70^{\circ} \mathrm{C}$ for $48 \mathrm{~h}$ then weighted.

\section{Yield and its components}

At harvest in mid April, samples of ten plants were collected at randomly from the central rows of each plot to study the following criteria: Plant height $(\mathrm{cm})$, number of branches/plant, number of pods/plant, weight of pods (g/plant), seed weight (g/ plant), and 100-seed weight (g). Seed yield (ard/ fad) was estimated from the whole of each plot.

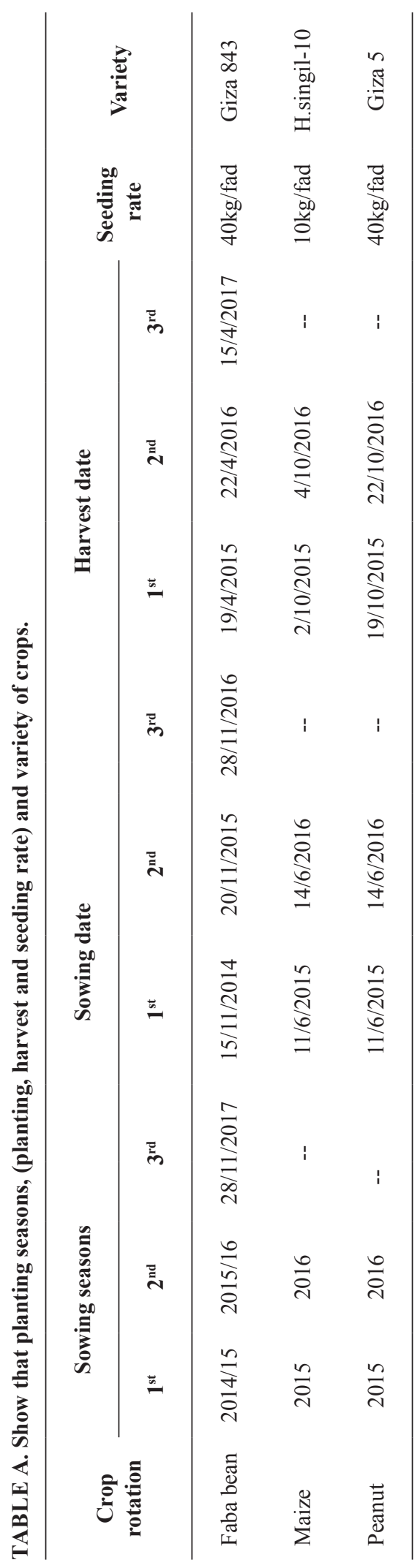

Egypt. J. Agron. 40, No.2 (2018) 
Statistical analysis

Differences among the treatment means were determined by Fisher's protected LSD at a significance level of 0.05 probability level according to Steel \& Torrie (1980). The weed species community by treatment was analyzed separately for each crop rotation using an analysis similar to that above. Data over seasons of seed yield was subjected to simple correlation coefficients and simple linear regression analysis according to Sendecor \& Cochran (1989) to construct the prediction model for weed species community in faba bean was performed. When $F$ was significant $(\mathrm{P}<0.05)$ for the levels of symptoms, a regression analysis was performed.

\section{Results and Discussion}

\section{Influence of crop rotation on}

Number of weeds $\left(\mathrm{m}^{2}\right)$

Data in Table 1 show that the effect of crop rotation was significant on number of weeds in 2014/15, 2015/16 and 2016/17 seasons. Crop ratation faba bean/ maize/faba bean/maize/faba bean $\left(1^{\text {st }}\right.$ system $)$ decreased numbers of hearbal, broad-leaved and total weeds $\left(\mathrm{g} / \mathrm{m}^{2}\right)$ among three seasons compared with faba bean/peanut/faba bean/peanut/ faba bean ( $2^{\text {nd }}$ system). Using of crop rotation $1^{\text {st }}$ system decreased numbers of grassy by $39.72,36.26$ and $33.88 \%$ and broad-leaved weeds by $19.22,5.00$ and $31.04 \%$, while over all weeds minimize by $27.23,17.38$, and $32.18 \%$ in the first, second and third seasons, respectively compared to $2^{\text {nd }}$ system.
These results may be due to the use of the first agricultural crop rotation which was more capable to reduce the number of weeds, because the maize has the effect of an inhibitor to the growth of weeds in the next winter season. Our results are harmony by Elian \& El-Mashed (1994), Hassanein et al. (2000) and Kookhki et al. (2009).

Dry weight of weeds $\left(\mathrm{g} / \mathrm{m}^{2}\right)$

Table 2 found that, using of $1^{\text {st }}$ system dropped the dry weight of grassy, total weeds and broadleaved college years. The crop rotation and that are shown in Table 2. Crop rotation faba bean/ maize/faba bean/ maize/faba bean ( $1^{\text {st }}$ system $)$ decresed significantly the dry grassy, broadleaved and total weeds in among three seasons. Grassy, broad-leaved and total weeds decrased significantly by $33.14,31.49$ and $32.013 \%$ in $2014 / 15$ seasons, by $32.14,31.97$ and $31.42 \%$ in $2015 / 16$ season and by $38.83,35.3$ and $36.69 \%$ in $2016 / 17$ season, compared with faba bean/peanut/ faba bean/peanut/ faba bean $\left(2^{\text {nd }}\right.$ system $)$.

Mature maize plants possess a number of (nine) water soluble allelochemicals which are phytotoxic to the growth of certain weeds such as Phalaris minor Retz., Chenopodium album L, Rumex dentatus $\mathrm{L}$ and Convolvulus arvensis L. Incorporation of sorghum roots suppressed the weed biomass by $25-50 \%$ and increased wheat yields by $7-8 \%$ (Cheema et al., 1997). These results agreement with Thorup et al. (2003), Buhler (2004) and Filizadeh et al. (2007).

TABLE 1. Effect of crop rotation on numbers of weeds $\left(\mathrm{g} / \mathrm{m}^{2}\right)$ in $2014 / 15,2015 / 16$ and $2016 / 17$ seasons.

\begin{tabular}{|c|c|c|c|c|c|c|c|c|c|}
\hline \multirow[t]{2}{*}{ Treatments } & \multicolumn{3}{|c|}{ Numbers of grassy weeds } & \multicolumn{3}{|c|}{$\begin{array}{c}\text { Numbers of broad-leaved } \\
\text { weeds }\end{array}$} & \multicolumn{3}{|c|}{ Numbers total weeds } \\
\hline & $2014 / 15$ & $2015 / 16$ & $2016 / 17$ & $2014 / 15$ & $2015 / 16$ & $2016 / 17$ & $2014 / 15$ & $2015 / 16$ & 2016/17 \\
\hline \multicolumn{10}{|c|}{ Crop rotation } \\
\hline $1^{\text {st }}$ system & 65.44 & 67.00 & 62.67 & 136.78 & 152.11 & 97.00 & 202.22 & 219.11 & 159.67 \\
\hline $2^{\text {nd }}$ system & 108.56 & 105.11 & 94.78 & 169.33 & 160.11 & 140.67 & 277.89 & 265.22 & 235.44 \\
\hline F-test & $* *$ & $* *$ & $* *$ & $* *$ & $* *$ & $* *$ & $* *$ & $* *$ & $* *$ \\
\hline
\end{tabular}

TABLE 2. Impact of crop rotation on dry weight of weeds $\left(\mathrm{g} / \mathrm{m}^{2}\right)$ in $2014 / 15,2015 / 16$ and $2016 / 17$ seasons.

\begin{tabular}{|c|c|c|c|c|c|c|c|c|c|}
\hline \multirow[t]{2}{*}{ Treatments } & \multicolumn{3}{|c|}{ Dry weight of grassy weeds } & \multicolumn{3}{|c|}{$\begin{array}{c}\text { Dry weight of broad-leaved } \\
\text { weeds }\end{array}$} & \multicolumn{3}{|c|}{ Dry weight of total weeds } \\
\hline & $2014 / 15$ & $2015 / 16$ & 2016/17 & $2014 / 15$ & $2015 / 16$ & $2016 / 17$ & $2014 / 15$ & $2015 / 16$ & 2016/17 \\
\hline \multicolumn{10}{|c|}{ Crop rotation } \\
\hline $1^{\text {st }}$ system & 101.33 & 98.78 & 95.70 & 166.33 & 163.44 & 161.22 & 267.66 & 262.22 & 256.92 \\
\hline $2^{\text {nd }}$ system & 156.44 & 151.56 & 145.56 & 252.67 & 242.67 & 233.56 & 409.11 & 394.23 & 379.12 \\
\hline F-test & $* *$ & $* *$ & $* *$ & $* *$ & $* *$ & $* *$ & $* *$ & $* *$ & $* *$ \\
\hline
\end{tabular}


Yield and its components

Data in Tables 3 and 4 showed significantly increase in number and weight of pods/plant (g) and seed weight/plant (g), 100-seed weight (g) and seed yield ( $\mathrm{ard} / \mathrm{fad})$ by following $1^{\text {st }}$ system, except for plant height in three seasons. Number of branches/plant was affected significantly in first seasons only compared to the following $2^{\text {nd }}$ system. Using of crop rotation $1^{\text {st }}$ system increased significantly the seed weight, 100-seed weight (g) and seed yield ( $\mathrm{ard} / \mathrm{fad}$ ) by 15.77, 8.26 and $8.54 \%$ in first season, by $19.63,5.78$ and $17.72 \%$ in second season and by $10.82,7.69$ and $9.18 \%$ in third season, respectively compared to $\left(2^{\text {nd }}\right.$ system). Low seed yield of faba bean grown after peanut because the direction of faba bean plants to vegetative growth and rampage plants, unlike seed growth. This is because the peanut grown in the summer season, leaving a large amount of nutrients especially nitrogen installer addition to fertilize faba bean per recommended. Since the maize crop overwrought soil, it does not leave too little nutrients. So, the faba bean planted after maize grows naturally therefore increasing seed yield output especially in light of the excellent weed control using herbicides or hoeing. Our results are harmony by Dogan et al. (2008), Mohammaddoust et al. (2009) and Demjanová (2009).

\section{Impact of weed control treatments sequence Number of weeds $\left(\mathrm{m}^{2}\right)$}

Table 5 revaled that the effect of weed control treatments was significante on numbers of grassy, broad-leaved and total weeds in 2014/15, 2015/16 and 2016/17 seasons. Harness at 1.0L/fad preemergence on weeds of maize/Fuslide super at $1.0 \mathrm{~L} / \mathrm{fad}+$ Basagran at $500 \mathrm{cc} / \mathrm{fad}$ at 30 days after sowing on peanut and faba bean decreased significantly numbers of grassy, broad-leaved and total weeds by $40.66,31.88$ and $37.45 \%$ in first season, by $63.95,55.45$ and $58.77 \%$ in second season and by $72.91,36.41$ and $54.21 \%$ in third seasoin, respectively. Hand hoeing twice in summer and winter seasons decreased significantly numbers of grassy, broad-leaved and total weeds by $68.13,94.60$ and $55.11 \%$ in first season, by $80.76,66.47$ and $72.06 \%$ in second season and by $72.91,65.90$ and $77.41 \%$ in third seasoin, respectively, compared with unweeded treatment.

TABLE 3. Effect of crop rotation on yield and it's components in 2014/15, 2015/16 and 2016/17 seasons.

\begin{tabular}{lcccccccccc}
\hline \multirow{2}{*}{ Treatments } & \multicolumn{3}{c}{ Plant height $(\mathbf{c m})$} & \multicolumn{3}{c}{ No. branches/plant } & \multicolumn{3}{c}{ Weight pods/plant (g) } \\
\cline { 2 - 10 } & $\mathbf{2 0 1 4 / 1 5}$ & $\mathbf{2 0 1 5 / 1 6}$ & $\mathbf{2 0 1 6 / 1 7}$ & $\mathbf{2 0 1 4 / 1 5}$ & $\mathbf{2 0 1 5 / 1 6}$ & $\mathbf{2 0 1 6 / 1 7}$ & $\mathbf{2 0 1 4 / 1 5}$ & $\mathbf{2 0 1 5 / 1 6}$ & $\mathbf{2 0 1 6 / 1 7}$ \\
\hline & 75.37 & 78.06 & 78.10 & 3.21 & 3.66 & 2.89 & 19.08 & 19.46 & 24.67 \\
\hline $1^{\text {st }}$ system & 86.51 & 91.71 & 88.08 & 2.20 & 3.40 & 2.67 & 16.32 & 16.86 & 19.24 \\
$2^{\text {nd }}$ system & $* *$ & $* *$ & $* *$ & NS & NS & NS & $* *$ & $* *$ & $* *$ \\
F-test & \multicolumn{1}{c}{ Crop rotation } \\
\hline
\end{tabular}

TABLE 4. Influence of crop rotation on yield and yield components in 2014/15, 2015/16 and 2016/17 seasons.

\begin{tabular}{lccccccccc}
\hline \multirow{2}{*}{ Treatments } & \multicolumn{3}{c}{ Weight seeds/plant (g) } & \multicolumn{1}{c}{$\mathbf{1 0 0 0}$-seed weight (g) } & \multicolumn{3}{c}{ Yield (ard/fad) } \\
\cline { 2 - 10 } & $\mathbf{2 0 1 4 / 1 5}$ & $\mathbf{2 0 1 5 / 1 6}$ & $\mathbf{2 0 1 6 / 1 7}$ & $\mathbf{2 0 1 4 / 1 5}$ & $\mathbf{2 0 1 5 / 1 6}$ & $\mathbf{2 0 1 6 / 1 7}$ & $\mathbf{2 0 1 4 / 1 5}$ & $\mathbf{2 0 1 5 / 1 6}$ & $\mathbf{2 0 1 6 / 1 7}$ \\
\hline & \multicolumn{1}{c}{ Crop rotation } \\
$1^{\text {st }}$ system & 13.80 & 14.52 & 15.05 & 72.96 & 73.42 & 75.61 & 5.37 & 5.58 & 6.09 \\
$2^{\text {nd }}$ system & 11.92 & 12.58 & 13.58 & 67.39 & 69.66 & 70.21 & 4.53 & 4.74 & 5.11 \\
F-test & $* *$ & $* *$ & $* *$ & $* *$ & $* *$ & $* *$ & $* *$ & $* *$ & $* *$ \\
\hline
\end{tabular}

TABLE 5. Effection of weed control treatments on dry weight of weeds $(\mathrm{g} / \mathrm{m} 2)$ in 2014/15, 2015/16 and 2016/17 seasons.

\begin{tabular}{|c|c|c|c|c|c|c|c|c|c|}
\hline \multirow[t]{2}{*}{ Treatments } & \multicolumn{3}{|c|}{ Numbers of grassy weeds } & \multicolumn{3}{|c|}{$\begin{array}{c}\text { Numbers of broad-leaved } \\
\text { weeds }\end{array}$} & \multicolumn{3}{|c|}{ Numbers total weeds } \\
\hline & $2014 / 15$ & $2015 / 16$ & $2016 / 17$ & $2014 / 15$ & $2015 / 16$ & 2016/17 & $2014 / 15$ & $2015 / 16$ & 2016/17 \\
\hline \multicolumn{10}{|c|}{ Weed control treatment sequence } \\
\hline Herbicide & 76.17 & 59.83 & 46.50 & 141.00 & 117.17 & 114.67 & 217.17 & 177 & 161.17 \\
\hline Hand hoeing twice & 44.67 & 32.00 & 18.00 & 111.17 & 88.17 & 61.50 & 155.84 & 120.17 & 79.5 \\
\hline Unweeded (check) & 140.17 & 166.33 & 171.67 & 207.00 & 180.33 & 263.00 & 347.17 & 346.66 & 434.67 \\
\hline LSD $_{0.05}$ & 8.17 & 7.39 & 5.92 & 9.06 & 9.18 & 18.59 & 9.38 & 9.67 & 17.63 \\
\hline
\end{tabular}


The number of weeds decreased gradually to the growing season of the last season using weed control treatment, while the number of weeds gradually increased in the treatment control. There was a clear effect of the treatment weed control used on summer crops. As the succession of the use of the herbicide or hoeing in the summer and the winter crop yields and had a clear decline in the number and weight of weeds. These results was in agreement with the results of Elian \& El-Mashed (1994), Hassanein et al. (2000) and Kookhki et al. (2009).

\section{Dry weight of weeds $\left(\mathrm{g} / \mathrm{m}^{2}\right)$}

Table 6 revaled that effect of weed control treatments was significant on broad-leaved, total weeds and dry weight of grassy in 2014/15, 2015/16 and 2016/17 seasons.

Harness/Fuslide super+Basagran (on weeds in summer and winter seasons) decreased significantly dry weight of grassy, broad-leaved and total weeds by $42.62,40.81$ and $41.52 \%$ in first season, by $60.45,60.68$ and $41.52 \%$ in second season and by $68.90,63.22$ and $65.50 \%$ in third seasoin, respectively. Hand hoeing twice in summer/hand hoeing twice in winter season decreased significantly dry weight of grassy, broad-leaved and total weeds by $60.07,54.23$ and $54.51 \%$ in first season, by $74.83,72.20$ and $73.22 \%$ in second season and by $78.49,74.16$ and
$75.90 \%$ in third seasoin, respectively, compared with unweeded treatment. Therefore, crop rotation and hand hoeing twice weed treatment strategy is mainly significant regard in evolution of sustainable and environmentally safe strategies for weed control. Elian \& El-Mashed (1994), Hassanein et al. (2000) and Kookhki et al. (2009).

\section{Yield and its components}

Data in Tables 7 and 8 stated that the effect of weed control treatments was significantly on yield and yield components in 2014/15, 2015/16 and 2016/17 seasons. Weed control treatments suqunce of Harness/Fuslide super+Basagran and hand hoeing twice in summer and winter seasons, incresed siginficantly number and weight of pods/ plant, weight of seeds/plant, seed weight 100 -seed weight and seed yield ( $\mathrm{ard} / \mathrm{fad})$ in three seasons. Harness/Fuslide super+Basagran increased the 100 -seed weight and seed yield ( $\mathrm{ard} / \mathrm{fad})$ by $(30.75,38.34$ and $31.91 \%)$ and $(57.39,67.16$ and $62.67 \%$ ) in frist, second and third seasoin, respectively. Hand hoeing twice in summer/hand hoeing twice in winter increased the 100 -seed weight and seed yield ( $\mathrm{ard} / \mathrm{fad})$ by $(39.88$ and $73.04 \%$ ) in frist season, by (49.27 and $92.54 \%$ ), in second season and by 40.71 and $121.10 \%$ in third seasoin, respectively, compared with unweeded treatment. These results was in same trend with the results of Elian \& El-Mashed (1994).

TABLE 6. Crop rotation and weed control treatments affected on dry weight of weeds $\left(\mathrm{g} / \mathrm{m}^{2}\right)$ in $2014 / 15,2015 / 16$ and $2016 / 17$ seasons.

\begin{tabular}{|c|c|c|c|c|c|c|c|c|c|}
\hline \multirow[t]{2}{*}{ Treatments } & \multicolumn{3}{|c|}{ Dry weight of grassy weeds } & \multicolumn{3}{|c|}{$\begin{array}{c}\text { Dry weight of broad-leaved } \\
\text { weeds }\end{array}$} & \multicolumn{3}{|c|}{ Dry weight of total weeds } \\
\hline & $2014 / 15$ & $2015 / 16$ & $2016 / 17$ & $2014 / 15$ & $2015 / 16$ & $2016 / 17$ & $2014 / 15$ & $2015 / 16$ & $2016 / 17$ \\
\hline \multicolumn{10}{|c|}{ Weed control treatments } \\
\hline Herbicide & 110.17 & 88.00 & 76.88 & 177.17 & 141.17 & 139.33 & 287.34 & 229.17 & 216.21 \\
\hline Hand hoeing twice & 76.67 & 56.00 & 53.17 & 137.00 & 98.50 & 99.17 & 213.67 & 154.5 & 152.34 \\
\hline Unweeded (check) & 192.00 & 222.50 & 247.17 & 299.33 & 354.33 & 383.83 & 491.33 & 576.83 & 631 \\
\hline $\mathrm{LSD}_{0.05}$ & 16.80 & 16.72 & 19.11 & 10.94 & 19.91 & 10.08 & 10.75 & 10.11 & 12.29 \\
\hline
\end{tabular}

TABLE 7. Crop rotation and weed control treatments sequence affected on yield and yield components in 2014/15, 2015/16 and 2016/17 seasons.

\begin{tabular}{lccccccccc}
\hline \multirow{2}{*}{ Treatments } & \multicolumn{3}{c}{ Plant height $(\mathbf{c m})$} & \multicolumn{3}{c}{ No. branches/plant } & \multicolumn{3}{c}{ Weight pods/plant (g) } \\
\cline { 2 - 9 } & $\mathbf{2 0 1 4 / 1 5}$ & $\mathbf{2 0 1 5 / 1 6}$ & $\mathbf{2 0 1 6 / 1 7}$ & $\mathbf{2 0 1 4 / 1 5}$ & $\mathbf{2 0 1 5 / 1 6}$ & $\mathbf{2 0 1 6 / 1 7}$ & $\mathbf{2 0 1 4 / 1 5}$ & $\mathbf{2 0 1 5 / 1 6}$ & $\mathbf{2 0 1 6 / 1 7}$ \\
\hline Herbicide & 82.73 & 85.27 & 86.67 & 3.58 & 3.75 & 3.00 & 19.90 & 19.73 & 21.03 \\
Hand hoeing twice & 85.05 & 87.60 & 90.50 & 3.77 & 3.67 & 3.00 & 20.47 & 21.60 & 27.76 \\
Unweeded (check) & 72.03 & 66.78 & 66.10 & 2.28 & 3.17 & 2.33 & 13.73 & 13.14 & 17.08 \\
LSD $_{0.05}$ & 7.38 & 5.91 & 5.52 & 0.91 & NS & 3.54 & 9.37 & 3.95 & 6.13 \\
\hline
\end{tabular}


TABLE 8. Effectiveness of crop rotation and weed control treatments sequence on yield and yield components in 2014/15, 2015/16 and 2016/17 seasons

\begin{tabular}{|c|c|c|c|c|c|c|c|c|c|}
\hline \multirow{2}{*}{ Treatments } & \multicolumn{3}{|c|}{ Weight seeds/plant } & \multicolumn{3}{|c|}{ 1000-seed weight (g) } & \multicolumn{3}{|c|}{ Yield (ard/fad) } \\
\hline & $2014 / 15$ & $2015 / 16$ & 2016/17 & $2014 / 15$ & $2015 / 16$ & $2016 / 17$ & $2014 / 15$ & $2015 / 16$ & $2016 / 17$ \\
\hline \multicolumn{10}{|c|}{ Weed control treatment sequence } \\
\hline Herbicide & 14.02 & 14.83 & 16.05 & 74.27 & 76.60 & 77.43 & 5.43 & 5.60 & 6.30 \\
\hline $\begin{array}{l}\text { Hand hoeing } \\
\text { twice }\end{array}$ & 15.37 & 16.88 & 18.27 & 79.45 & 82.65 & 82.60 & 5.97 & 6.45 & 7.23 \\
\hline $\begin{array}{l}\text { Unweeded } \\
\text { (check) }\end{array}$ & 9.48 & 9.20 & 8.93 & 58.70 & 55.37 & 56.80 & 3.45 & 3.35 & 3.27 \\
\hline $\operatorname{LSD}_{0.05}$ & 1.51 & 3.59 & 3.52 & 6.57 & 5.22 & 4.91 & 3.86 & 3.46 & 3.36 \\
\hline
\end{tabular}

Impact of interactions

Crop rotation and weed control treatments affected significantly on the all studied weed population traits. Faba bean/maize/faba bean/ maize/faba bean $\left(1^{\text {st }}\right.$ system $)$ decreased all weed population number and weight traits. Whereas, crop rotation decrease total weed number and weed dry biomass was received in hand hoeing twice weed control treatment.

Number and dry weight of weeds $\left(m^{2}\right)$

Results obtained in Tables 9 and 10 indicated that interaction between crop rotation and weed control treatments significantly affected number and dry weight of grassy as will as broad-leaved and total weeds. It noticed significantly less total weed number and dry weight of weeds was received in hand hoeing twice weed control treatment under $1^{\text {st }}$ system (Faba bean/ maize/faba bean/ maize/faba bean) for grassy weeds number in $3^{\text {rd }}$ season, broad-leaved weeds number in $2^{\text {nd }}$ season, total weeds number in $2^{\text {nd }}$ season and grassy, broad-leaved and total weeds dry weight in the $2^{\text {nd }}$ season and $3^{\text {rd }}$ season. These results was in harmony with the Elian \& El-Mashed (1994), Hassanein et al. (2000) and Kookhki et al. (2009).

Yield and its components

Tables 11 and 12 shown the interaction between crop rotations and weed control treatments, there were significant differences for weight of seeds/plant and seed yield ( $\mathrm{ard} / \mathrm{fad})$ in the $3^{\text {rd }}$ season. The highest values in these traits was recorded in hand hoeing twice weed control treatment under $1^{\text {st }}$ system (Faba bean/ maize/faba bean/ maize/faba bean).

Therefore, results showed the significant effect among the crop rotations and weed treatments for some yield traits. Crop rotations improve crop growth and yield traits. $1^{\text {st }}$ system (Faba bean/ maize/faba bean/maize/faba bean) had the highest faba bean seed yield. Hand hoeing twice weed control treatment recorded the highest values seed yield. These results was in agreement with Elian \& El-Mashed, (1994), Hassanein et al. (2000) and Kookhki et al. (2009).

TABLE 9. Interactions between crop rotation and weed control treatments sequence on dry weight of weeds $\left(\mathrm{g} / \mathrm{m}^{2}\right)$ in $2014 / 15,2015 / 16$ and $2016 / 17$ seasons.

\begin{tabular}{|c|c|c|c|c|c|c|c|c|c|c|}
\hline \multirow{2}{*}{$\begin{array}{l}\text { Crop } \\
\text { rotation }\end{array}$} & \multirow{2}{*}{$\begin{array}{l}\text { Weed control } \\
\text { treatments }\end{array}$} & \multicolumn{3}{|c|}{ Numbers of grassy weeds } & \multicolumn{3}{|c|}{$\begin{array}{c}\text { Numbers of broad-leaved } \\
\text { weeds }\end{array}$} & \multicolumn{3}{|c|}{ Numbers of total weeds } \\
\hline & & $2014 / 15$ & $2015 / 16$ & $2016 / 17$ & $2014 / 15$ & $2015 / 16$ & 2016/17 & $2014 / 15$ & $2015 / 16$ & $2016 / 17$ \\
\hline \multirow{3}{*}{$1^{\text {st }}$ system } & Herbicide & 48.00 & 36.67 & 23.67 & 127.00 & 108.33 & 99.00 & 175.00 & 145.00 & 122.67 \\
\hline & Hand hoeing twice & 26.33 & 20.00 & 12.33 & 88.33 & 68.00 & 50.67 & 114.67 & 88.00 & 63.00 \\
\hline & Unweeded (check) & 122.00 & 144.33 & 152.00 & 195.00 & 280.00 & 141.33 & 317.00 & 424.33 & 293.33 \\
\hline \multirow{3}{*}{$2^{\text {nd }}$ system } & Herbicide & 104.33 & 83.00 & 69.33 & 155.00 & 126.00 & 130.33 & 259.33 & 209 & 199.66 \\
\hline & Hand hoeing twice & 63.00 & 44.00 & 23.67 & 134.00 & 108.33 & 72.33 & 197.00 & 152.33 & 96.00 \\
\hline & Unweeded (check) & 158.33 & 188.33 & 191.33 & 19.33 & 220.00 & 246.00 & 177.66 & 408.33 & 437.33 \\
\hline \multicolumn{2}{|c|}{ L. S. D. at ${ }_{0.05}$} & 10.20 & 9.10 & 7.02 & 9.06 & 11.63 & 24.94 & 11.91 & 12.33 & 23.58 \\
\hline
\end{tabular}


TABLE 10. Effect of interactions between crop rotation and weed control treatments sequence on dry weight of weeds $\left(\mathrm{g} / \mathrm{m}^{2}\right)$ in $2014 / 15,2015 / 16$ and $2016 / 17$ seasons.

\begin{tabular}{|c|c|c|c|c|c|c|c|c|c|c|}
\hline \multirow{2}{*}{$\begin{array}{c}\text { Crop } \\
\text { rotation } \\
\end{array}$} & \multirow{2}{*}{$\begin{array}{c}\text { Weed control } \\
\text { treatment sequence }\end{array}$} & \multicolumn{3}{|c|}{$\begin{array}{c}\text { Dry weight of grassy } \\
\text { weeds }\end{array}$} & \multicolumn{3}{|c|}{$\begin{array}{l}\text { Dry weight of broad- } \\
\text { leaved weeds }\end{array}$} & \multicolumn{3}{|c|}{ Dry weight of total weeds } \\
\hline & & $2014 / 15$ & 2015/16 & 2016/17 & $2014 / 15$ & $2015 / 16$ & 2016/17 & $2014 / 15$ & $2015 / 16$ & 2016/17 \\
\hline \multirow{3}{*}{$1^{\text {st }}$ system } & Herbicide & 86.33 & 69.67 & 58.10 & 124.67 & 102.33 & 85.00 & 211.00 & 172.00 & 143.10 \\
\hline & Hand hoeing twice & 50.00 & 38.33 & 32.67 & 110.33 & 84.67 & 75.33 & 160.33 & 123.00 & 108.10 \\
\hline & Unweeded (check) & 167.67 & 188.33 & 196.33 & 264.00 & 296.67 & 330.00 & 431.67 & 485.00 & 526.33 \\
\hline \multirow{3}{*}{$\begin{array}{l}2^{\text {nd }} \\
\text { system }\end{array}$} & Herbicide & 134.00 & 106.33 & 95.33 & 229.67 & 176.33 & 197.33 & 363.67 & 282.67 & 293.67 \\
\hline & Hand hoeing twice & 103.33 & 73.67 & 73.67 & 163.67 & 112.33 & 123.00 & 267.00 & 187.00 & 196.67 \\
\hline & Unweeded (check) & 216.33 & 256.67 & 300.00 & 334.67 & 412.00 & 437.67 & 551.00 & 667.67 & 737.67 \\
\hline \multicolumn{2}{|c|}{ L. S. D. at ${ }_{0.05}$} & 18.27 & 18.16 & 11.54 & 14.12 & 12.67 & 12.91 & 13.85 & 12.95 & 16.03 \\
\hline
\end{tabular}

Table 11. Interactions between crop rotation and weed control treatments sequence on yield and it's components in $2014 / 15,2015 / 16$ and $2016 / 17$ seasons.

\begin{tabular}{|c|c|c|c|c|c|c|c|c|c|c|}
\hline \multirow[b]{2}{*}{ Crop rotation } & \multirow{2}{*}{$\begin{array}{l}\text { Weed control } \\
\text { treatment sequence }\end{array}$} & \multicolumn{3}{|c|}{ Plant height (cm) } & \multicolumn{3}{|c|}{ No. branches } & \multicolumn{3}{|c|}{ Weight pods/plant (g) } \\
\hline & & $2014 / 15$ & $2015 / 16$ & 2016/17 & $2014 / 15$ & $2015 / 16$ & 2016/17 & $2014 / 15$ & $2015 / 16$ & 2016/17 \\
\hline \multirow{3}{*}{$1^{\text {st }}$ system } & Herbicide & 79.70 & 81.60 & 83.63 & 3.30 & 3.90 & 3.92 & 20.37 & 20.77 & 21.90 \\
\hline & Hand hoeing twice & 82.13 & 85.77 & 82.97 & 3.90 & 3.60 & 3.77 & 22.17 & 23.73 & 34.70 \\
\hline & Unweeded (check) & 64.27 & 63.80 & 61.70 & 2.43 & 3.47 & 2.33 & 14.70 & 13.87 & 17.43 \\
\hline \multirow{3}{*}{$2^{\text {nd }}$ system } & Herbicide & 87.77 & 88.93 & 89.70 & 3.87 & 3.60 & 3.00 & 17.43 & 18.70 & 20.17 \\
\hline & Hand hoeing twice & 88.97 & 89.43 & 93.03 & 3.63 & 3.73 & 2.67 & 18.77 & 19.47 & 20.82 \\
\hline & Unweeded (check) & 79.80 & 66.77 & 69.50 & 2.13 & 2.87 & 2.33 & 12.77 & 12.40 & 16.73 \\
\hline L. S. D. at ${ }_{0.05}$ & & 4.35 & 3.28 & 6.46 & NS & NS & 3.66 & 13.24 & 4.23 & 7.32 \\
\hline
\end{tabular}

TABLE 12. Impact of interactions between crop rotation and weed control treatments sequence on yield and it's components in 2014/15, 2015/16 and 2016/17 seasons.

\begin{tabular}{|c|c|c|c|c|c|c|c|c|c|c|}
\hline \multirow[b]{2}{*}{ Crop rotation } & \multirow{2}{*}{$\begin{array}{l}\text { Weed control } \\
\text { treatment sequence }\end{array}$} & \multicolumn{3}{|c|}{ Weight seeds/plant (g) } & \multicolumn{3}{|c|}{ 100-seed weight (g) } & \multicolumn{3}{|c|}{ Yield (ard/fad) } \\
\hline & & 2014/15 & $2015 / 16$ & $2016 / 17$ & $2014 / 15$ & $2015 / 16$ & $2016 / 1$ & $2014 / 15$ & $2015 / 10$ & 2016/17 \\
\hline \multirow{3}{*}{$1^{\text {st }}$ system } & Herbicide & 15.43 & 16.20 & 17.63 & 77.27 & 78.93 & 80.07 & 5.97 & 6.27 & 7.07 \\
\hline & Hand hoeing twice & 16.43 & 18.20 & 19.27 & 82.90 & 84.70 & 86.30 & 6.40 & 6.77 & 7.60 \\
\hline & Unweeded (check) & 9.53 & 9.17 & 9.70 & 58.70 & 56.63 & 60.47 & 3.73 & 3.70 & 3.60 \\
\hline \multirow{3}{*}{$2^{\text {nd }}$ system } & Herbicide & 12.60 & 13.47 & 14.47 & 71.27 & 74.27 & 74.80 & 4.90 & 5.10 & 5.53 \\
\hline & Hand hoeing twice & 14.30 & 15.77 & 17.27 & 76.00 & 78.90 & 80.60 & 5.53 & 6.13 & 6.87 \\
\hline & Unweeded (check) & 9.27 & 8.87 & 8.70 & 54.90 & 54.10 & 56.93 & 3.17 & 3.00 & 2.93 \\
\hline L. S. D. at ${ }_{0.05}$ & & 2.14 & 3.72 & 6.63 & 9.29 & 6.03 & 5.59 & 2.22 & 3.55 & 3.41 \\
\hline
\end{tabular}

Correlation analysis

The simple correlation coefficient for all comparisons among the studied traits is presented in Table 13. Significant positive correlation values were detected between seed yield ( $\mathrm{ard} / \mathrm{fad})$ and each of plant height $(\mathrm{cm})\left(\mathrm{r}=0.81^{* *}\right)$, number of branches/plant $\left(\mathrm{r}=0.43^{* *}\right)$, pods weight ( $\left.\mathrm{g} / \mathrm{plant}\right)$ $\left(\mathrm{r}=0.41^{* *}\right)$, 100-seed weight $(\mathrm{g})\left(\mathrm{r}=0.910^{* *}\right)$ and seeds weight ( $\mathrm{g} / \mathrm{plant})\left(\mathrm{r}=0.93^{* *}\right)$. These findings indicate that selection for each or both of seed yield components would be accompanied by high yielding potentiality under such conditions.

Negative and significant correlations were observed between seed yield $(\mathrm{ard} / \mathrm{fad})$ and each of dry weight of grassy weeds $\left(\mathrm{g} / \mathrm{m}^{2}\right)\left(\mathrm{r}=-0.92^{* *}\right)$, dry weight of broad-leaved weeds $\left(\mathrm{g} / \mathrm{m}^{2}\right)\left(\mathrm{r}=-0.92^{* *}\right)$, dry weight of total grassy and broad-leaved weeds $\left(\mathrm{g} / \mathrm{m}^{2}\right)\left(\mathrm{r}=-0.93^{* *}\right)$, numbers of grassy weeds $\left(\mathrm{m}^{2}\right)$ $\left(\mathrm{r}=-0.94^{* *}\right)$, numbers of broad-leaved weeds $\left(\mathrm{m}^{2}\right)$ $\left(r=-0.84^{* *}\right)$, numbers of total grassy and broadleaved weeds $\left(\mathrm{m}^{2}\right),\left(\mathrm{r}=-0.92^{* *}\right)$. The same trend 
of negative significant correlation between seed yield and weed control treatments traits was recorded in Table 5.

These findings indicate that selection for each or both of seed yield components would be accompanied by high yielding potentiality under such conditions. The same trend of negative significant correlation is recorded between seed yield and weed control treatments traits.

\section{Economic analysis}

Table 14 clears the net return of the three treatments in the first rotation of faba bean and maize which shows that the average price of the crop is estimated at 766 pounds/ardeb while the average price of hay heml about 131 pounds, and the rent cost of feddan is estimated at 1873 pounds. In the light of the results obtained, the average yield, when conducting the first, second and third treatments is estimated at $6.43,6.92$ and $3.68 \mathrm{ardeb} /$ faddan, respectively, while the variable costs of production is estimated at $2702,0.3221$ and 0.2819 pounds/faddan for the three treatments, respectively. By estimating revenue of the yield (major and minor), it reaches about 5848, 6224 and 3707 pounds when conducting the first, second and third treatments, respectively. Deducting the total costs (variable + fixed) from the total yield revenue to estimate the net return/faddan for the three treatments. It reaches about 1273 pounds for the first treatment and 1130pounds for the second treatment but the third treatment has achieved loss amounted to 985pounds/faddan. Therefore, the first treatment (Fuslide super+Basagran) is the best treatment for the first rotation and it is recommended to apply.

Table 15 shows the net return of the three treatments in the second rotation of faba bean and peanuts which indicates that the average price of the crop is estimated at 766pounds/ardeb while the average price of a heml of hay is 131 pounds and the rent cost of the feddan is 1873pounds. In the light of the obtained results, the average yield is estimated at 5.18, 6.18 and 3.03ardeb/ faddan when conducting the first, second and third treatments, respectively. The production variable costs is estimated at 2702, 0.3221 and 0.2819 pounds/faddan for the three treatments, respectively. By estimating yield revenue (major and minor), it reaches about 4874, 5655 and 3212 pounds when carrying out the first, second and third treatments, respectively. The results cleared that the net return per feddan after deducting the total costs (variable + fixed) from the total yield revenue, for the three treatments, reaches 299 pounds/faddan for the first treatment, 56 pounds/ faddan for the second treatment while the third treatment did not give any profits which made a loss of about 1479pounds/faddan. Therefore, the second treatment (Hand hoeing twice) is the best treatment for the second rotation and applying it is recommended.

The study recommends cultivating faba bean crop with maize using Fuslide super+Basagran which gives the highest return for the crop achieving a profit for the farmer while cultivating faba bean crop with peanuts with hand hoeing twice gives a net return higher for the crop.

TABLE 13. Simple correlation between weed control treatments and some yield attributes.

\begin{tabular}{|c|c|c|c|c|c|c|c|c|c|c|c|}
\hline Trait & $\begin{array}{c}\text { Plant } \\
\text { height } \\
\text { cm }\end{array}$ & $\begin{array}{c}\text { No. of } \\
\text { branches/ } \\
\text { plant }\end{array}$ & $\begin{array}{c}\text { Pods } \\
\text { weight/ } \\
\text { plant } \\
\text { g }\end{array}$ & $\begin{array}{c}100- \\
\text { seed } \\
\text { weight } \\
\mathrm{g}\end{array}$ & $\begin{array}{c}\text { grassy } \\
\text { weeds } \\
\mathbf{g} / \mathbf{m}^{2}\end{array}$ & $\begin{array}{c}\text { broad- } \\
\text { leaved } \\
\text { weeds } \\
\mathrm{g} / \mathrm{m}^{2}\end{array}$ & $\begin{array}{c}\text { Total } \\
\text { weeds } \\
\mathrm{g} / \mathrm{m}^{2}\end{array}$ & $\begin{array}{l}\text { No. of } \\
\text { grassy } \\
\text { weeds }\end{array}$ & $\begin{array}{l}\text { No. of } \\
\text { broad- } \\
\text { leaved } \\
\text { weeds }\end{array}$ & $\begin{array}{c}\text { No. of } \\
\text { total } \\
\text { weeds }\end{array}$ & $\begin{array}{c}\text { Seeds } \\
\text { weight } \\
\text { g }\end{array}$ \\
\hline No. of branches & $0.43^{* *}$ & & & & & & & & & & \\
\hline Pod weight/plant & 0.26 & 0.04 & & & & & & & & & \\
\hline 100-weight & $0.86^{* *}$ & $0.42^{* *}$ & $0.34^{*}$ & & & & & & & & \\
\hline Grassy weeds & $-0.86^{* *}$ & $-0.39^{* *}$ & $-0.32^{*}$ & $-0.91^{* *}$ & & & & & & & \\
\hline Broad-leaved & $-0.87^{* *}$ & $-0.38^{* *}$ & $-0.32^{*}$ & $-0.91^{* *}$ & $0.97^{* *}$ & & & & & & \\
\hline Total weeds & $-0.87^{* *}$ & $-0.38^{* *}$ & $-0.32^{*}$ & $-0.92^{* *}$ & $0.99^{* *}$ & $0.99^{* *}$ & & & & & \\
\hline $\begin{array}{l}\text { No. grassy } \\
\text { weeds }\end{array}$ & $-0.87^{* *}$ & $-0.40^{* *}$ & $-0.39^{* *}$ & $-0.92^{* *}$ & $0.97^{* *}$ & $0.97^{* *}$ & $0.97^{* *}$ & & & & \\
\hline No. broad-leaved & $-0.76^{* *}$ & $-0.35^{* *}$ & $-0.41^{* *}$ & $-0.87^{* *}$ & $0.82^{* *}$ & $0.83^{* *}$ & $0.84^{* *}$ & $0.84^{* *}$ & & & \\
\hline No. total weeds & $-0.84^{* *}$ & $-0.39^{* *}$ & $-0.41^{* *}$ & $-0.93^{* *}$ & $0.93^{* *}$ & $0.93^{* *}$ & $0.94^{* *}$ & $0.96^{* *}$ & $0.96^{* *}$ & & \\
\hline Seed weight/p & $0.86^{* *}$ & $0.41^{* *}$ & $0.42^{* *}$ & $0.92^{* *}$ & $-0.89^{* *}$ & $-0.91^{* *}$ & $-0.91^{* *}$ & $-0.93^{* *}$ & $-0.87^{* *}$ & $-0.93^{* *}$ & \\
\hline Yield (Ard.fad) & $0.81^{* *}$ & $0.43^{* *}$ & $0.41^{* *}$ & $0.91^{* *}$ & $-0.92^{* *}$ & $-0.92^{* *}$ & $-0.93^{* *}$ & $-0.94^{* *}$ & $-0.84^{* *}$ & $-0.92^{* *}$ & $0.93^{* *}$ \\
\hline
\end{tabular}




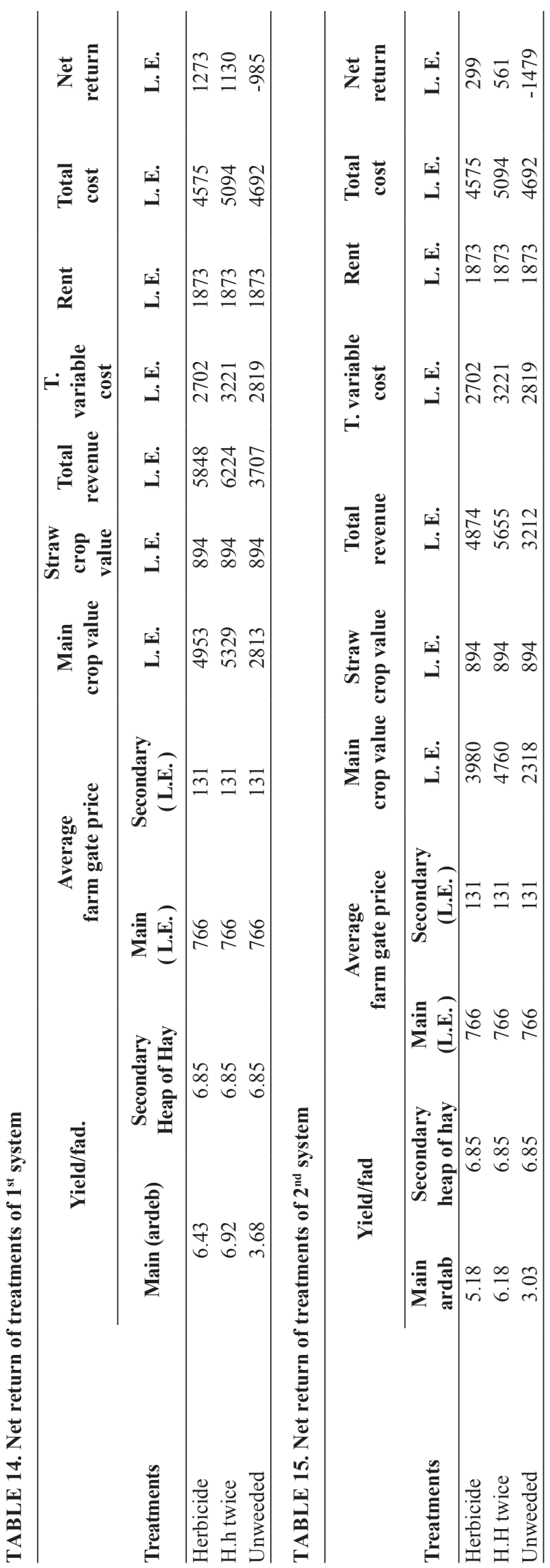

\section{Conclusion}

Crop rotation and hand hoeing twice weed treatment play strategic role in fact significant considerations in expansion of sustainable and environmentally safe strategies for weed control and faba bean seed yield. These findings indicate that selection for each or both of seed yield components would be accompanied by high yielding potentiality under such conditions. The same trend of negative significant correlation is recorded between seed yield and weed control treatments traits.

\section{$\underline{\text { References }}$}

Abasalt, R.A., Morad, S., Ghorban, D.M. and Kamran, M. (2014) Effect of cultivation time and weed control on weed and some characteristics of broad bean (Vicia faba L). Copyrights@2014 IJPAES ISSN 2231-4490.

Al-Akkad, M. (1994) Advanced Course of integrated Weed control. Management Development Center, El- Kanater El-Khyria, Kalubia Governorate, Egypt.

Buhler, D.D. (2004) Challenges and opportunities for integrated weed management. Weed Sci. 50, 273280.

Cheema, Z.A., Luqman, M. and Khaliq, A. (1997) Use of allelopathic extracts of maize, sorghum and sunflower herbage for weed control in wheat. $J$. Animal Plant Sci. 7, 91-93.

Davies, D.H.K., Christal, A., Talb, T.M., Lawson, H.M. and Wright, G.Mc.N. (1997) Changes in weed population in the conversion of two arable farms of organic farming. Brighton Crop Prot., Conf., Weed, Vol. 3, pp. 973-978.

Demjanová, E., Macák, M., Dalovic, I., Majerník, F., Štefan Týr and Jozef Smatana1 (2009) Effects of tillage systems and crop rotation on weed density weed species composition and weed biomass in maize. Agronomy Research, 7(2), 785-792.

Dogan, R., Goksoy, T.A., Yagdi, K. and Turan, M.Z. (2008) Comparison of the effects of different crop rotation systems on winter wheat and sunflower under rain-fed conditions. African Journal of Biotechnology, 7(22), 4076-4082. 
Ebaid, M.A. (1990) Effect of weed control method and irrigation number on growth and yield of field bean (Vicia faba L). Annals of Agric. Sci., Moshtohor, 28(3), 1429-1439.

Elian, M.A. and El -Mashed, L.E. (1994) Study the effect of inter row spacing on the control of broad leaf and grassy weeds on wheat yield, Nile valley regional program for wild oats control in cereals and some other winter crops. $2^{\text {nd }}$ Ann. Meet, 11-15 Sept., Cairo, Egypt, pp. 250-255.

El-Metwally, I.M. and Ahmed, S.A. (2001) Growth, yield and yield components of mung bean as affected by phosphorus levels and some weed control treatments. Annual of Agric. Sci. Moshtoher, 39(2), 787-803.

Filizadeh, Y., Rezazadeh, A. and Younessi, Z. (2007) Effects of crop rotation and tillage depth on weed competition and yield of rice in the paddy fields of Northern Iran. J. Agric. Sci. Technol. 9, 99-105.

Hassanein, E.E. and Al Marsafy, H.T. (1994) Estimate the degree of wheat seed infestation by wild oat and other weed seeds. Nile valley Regional program for wild oats control in cereals and some other winter crops. $2^{\text {nd }}$ Ann. Meet, 11 -15 Sept., Cairo, Egypt, pp. 152-156.

Hassanein, E.E. and Al Marsafy, H.T. (1995) Inspection of wheat seeds in Sohag governorate. Nile valley Regional program for wild oats control in cereals and some other winter crops. $3^{\text {rd }}$ Ann. Meet, 10-14 Sept., Cairo, Egypt, pp. 197-204.

Hassanein, E.E., Mekhail, G.M and Hassan, H.S. (1999) Effect of sowing methods on wheat and associated weeds. Nile valley Regional program for wild oats control in cereals and some other winter crops. $7^{\text {th }}$ Ann. Meet, 5-9 Sept., Cairo, Egypt, pp. 201-206.

Hassanein, E.E., Mekhail, G.M. and Hassan, H.S. (2000) Effect of sowing methods on wheat and associated weeds. Nile valley Regional program for wild oats control in cereals and some other winter crops. $8^{\text {th }}$ Ann. Meet, 3-7 Sept., Cairo, Egypt, pp. 204-210.

Heath., M.C., Clarke, J.H. and Dgilvy, S.E. (1991) Comparison of pre- and post-emergence herbicides for the control of broadleaved and grass weeds in spring field beans. Aspects of Applied Biology, 27, 167-172.
Ismail, A.E.A. and Fakkar, A.A.O. (2008) Faba bean yield losses due to Orobanche infestation and effect of plant density and weed control on annual weeds and Orobanche and faba bean productivity. Minia J. Agric. Res. Develop. 28(4), 627-246.

Karlen, D.L., Varvel, E.G., Bullock, G.D and Cruse, M.R. (1994) Crop rotation for the $21^{s t}$ century. $A d v$. Agron. 53, 1-45.

Koocheki, A., Nassiri, M., Alimoradi, L. and Ghorbani, R. (2009) Effect of cropping systems and crop rotations on weeds. Agron. Sustain. Dev. 29, 401-408.

Kropff, M.J. and Walter, H. (2000) EWRS and the challenges for weed research at the start of a new millennium. Weed Sci. 40(1), 7-10.

Liebman, M. and Dyck, E. (1993) Crop rotation and intercropping strategies for weed management. Ecol. Appl. 3, 92-122.

Mohammaddoust, C.H.R., Ghorbani, A., Asghari, A., Tulikov, A.M. and Zargarzadeh, F. (2009) Longterm effects of crop rotation and fertilizers on weed community in spring barley. Turk. J. Agric For. 33, 315-323.

Nehra, O.P. and Malik, R.K. (1999) Weed management studies in faba bean (Vicia faba L). Indian J. of Weed Sci. 31(3/4), 130-132.

Saad El-Din, S.A. (2003) Efficiency of some weed control treatments on growth, yield and its components of broad bean (Vicia faba L). Egypt. J. Appli. Sci. 18(6B), 586-604.

Sendecor, G.W. and Cochran, W.G. (1989) "Statistical Methods", Eighth edition, Iowa State University.

Steel, G.D. and Torrie, J.H. (1980) "Principles and Procedures of Statistical: A Biometrical Approach". New York: McGraw-Hill, 1980, 475p.

Thorup-Kristensen, K., Magid, J. and Jensen, L.S. (2003) Catch crops and green manures as biological tools in nitrogen management in temperate zones. Adv. Agron. 79, 227-302.

Stanger, T.F. and Lauer, J.G. (2008) Corn grain yield response to crop rotation and nitrogen over 35 years. Agronomy Journal, 100(3), 643-650.

Wibberley, J. (1996) A brief history of rotations, 
economic considerations and future directions. Aspects of Applied Biology, 47, 1-10.

Wu, H., Partley, J., Jemerle, D. and Haig, T. (1999) Crop cultivars with allelopathic capability. Weed Res. 39, $171-180$

Zentner, R.P., Wall, D.D., Nagy, C.N., Smith, E.G.,
Young, D.L., Miller, P.R., Campbell, C.A., Campbell, B.G., Brandt, S.A., Lafond, G.P., Johnston, A.M. and Derksen, D.A. (2002) Economics of crop diversification and soil tillage opportunities in the Canadian prairies. Agron. J. 94, 216-230.

\title{
تأثير الاورة الزراعية وتعاقب معاملات مكافحة الحشائش علي الحشائش وإنتاجية محصول الفول البلاي

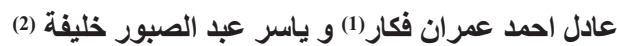

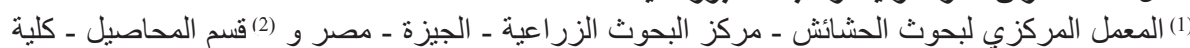

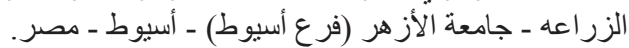

\begin{abstract}
يعتقد أن تناوب المحاصيل تقلل من كثافة الحشائش، وبالتالي منع تفاقم بعض المشاكل الناتجة من هذه الحشائش.

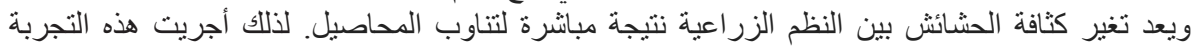

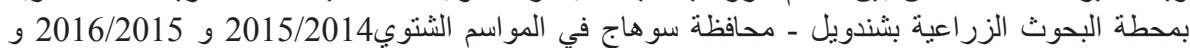

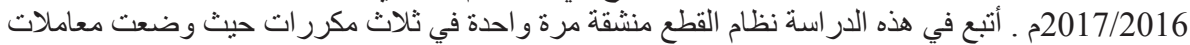

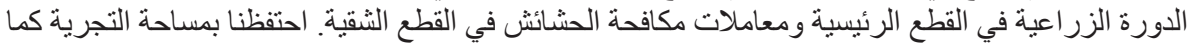

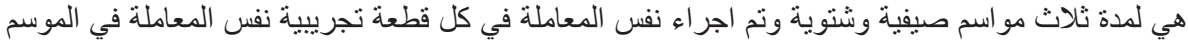

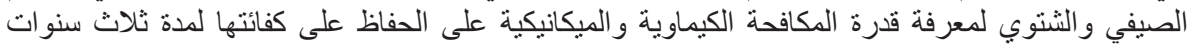
متتالية. وكانت أهم النتائج المتحصل فئرة عليها كما يلي:

أثرت الدورة الزراعية معنويا على عدد ووزن الحشائش العريضة و الضيقة و الكلية في المواسم الثلاثة

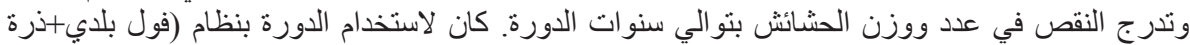

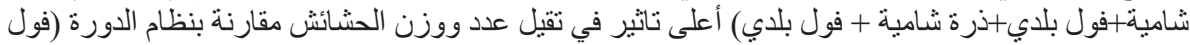

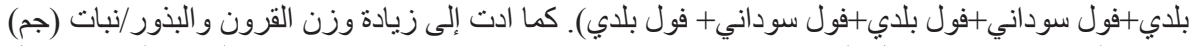

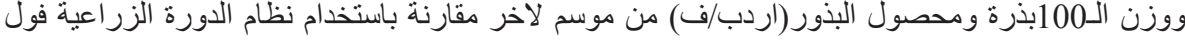

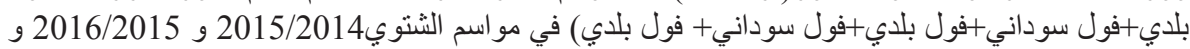
2017/2016 على التو الى. فلى بلى
\end{abstract}

أتضح أن تعاقب معاملات مكافحة الحشائش كان لة مردود قوي في تقليل عدد ووزن الحشائش العريضة

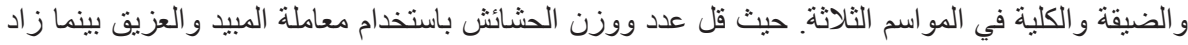

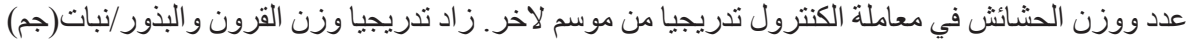

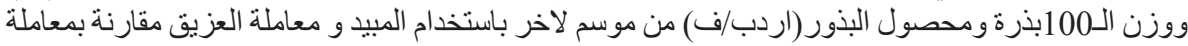

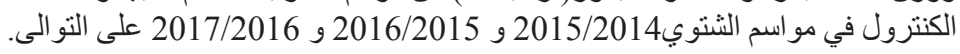

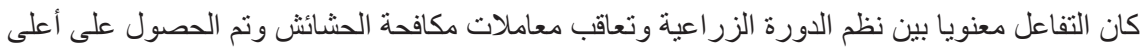

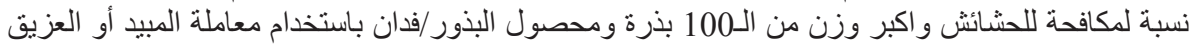

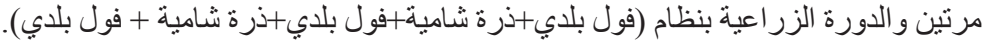

كان هنالك ارتباطا معنويا موجبا بين عدد الحشائش الضيقة وعريضة الأوراق و الكلية (م²) ووزنها (جم/2مّا2)

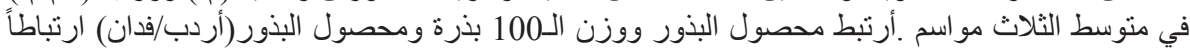

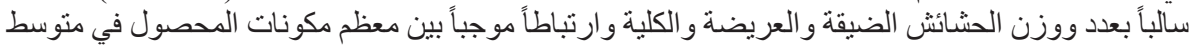
الثناث مو اسم.

أشار التقييم الاقتصادي إلى أن نظام الدورة الزر اعية (فول بلدي+ذرة شامية+فول بلدي+ذرة شامية + فئل فول

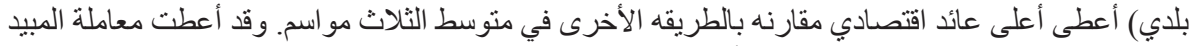

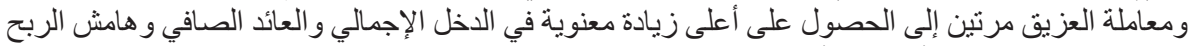

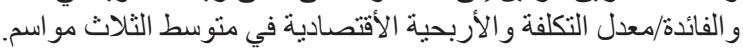

الخلاصة أن تناوب المحاصيل يعتبر مفيداً في إنتاج الفول للحد من ضرر الحشائش. ولذللك، تعتبر استر اتيجية

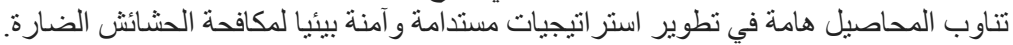

